\title{
TIME FOR CLEANING AND ROOM PREPARATION: CONNECTION BETWEEN SURGERY SIZE AND PROFESSIONAL PERSPECTIVES
}

\author{
Marla Andréia Garcia de AVILAa, Suzimar de Fátima Benato FUSCO ${ }^{\mathrm{b}}$, Ivana Regina GONÇALVES ${ }^{\text {, }}$ \\ Sílvia Maria CALDEIRA ${ }^{\mathrm{d}}$, Carlos Roberto PADOVANI ${ }^{\mathrm{e}}$, Hugo Hyung Bok YOO
}

\section{ABSTRACT}

The objective was to verify the association between time needed for room cleaning (TLPS) and the surgery size, and related advantages and difficulties faced by the circulator of the room assigned to this task. A mixed method, with a transverse quantitative, retrospective approach, using a sample of 3095 surgeries performed, from January to June 2011, and a qualitative approach using a Thematic Content Analysis of statements from 11 circulators, was used. The average TLPS was smaller in size 1 surgeries, increasing in sizes 2, 3 and 4, with a significant difference. Advantages reported included organization and size of staff, and difficulties reported related to sharp, bladed materials mixed with surgical instruments and a reduced number of cleaning professionals. The larger the size, the higher the TLPS. Surgical teams operating in the Surgical Center interfere directly in the process, facilitating or hindering the achievement of institutional goals related to quality and productivity.

Descriptors: Operating room nursing. Management indicators. Surgical procedures, operative.

\section{RESUMO}

Objetivou-se verificar a associação entre tempo de limpeza e preparo de sala cirúrgica (TLPS) com o porte cirúrgico, bem como relacionar facilidades e dificuldades atribuídas a essa tarefa pelos circulantes de sala. Método misto com abordagem quantitativa transversal, retrospectiva, com amostra de 3095 cirurgias realizadas de janeiro a junho de 2011, e abordagem qualitativa pela Análise de Conteúdo Temática acerca do discurso de 11 circulantes. A média do TLPS foi menor nas cirurgias de porte 1, aumentando nos portes $2,3 \mathrm{e} 4 \mathrm{com}$ diferença significativa. As facilidades relatadas foram sobre organização $e$ dimensionamento de pessoal, e as dificuldades, sobre materiais perfurocortantes misturados ao instrumental cirúrgico e número reduzido de profissionais da limpeza. Quanto maior o porte cirúrgico, maior o TLPS. As equipes atuantes no Centro Cirúrgico interferem diretamente no processo, facilitando ou dificultando o alcance das metas institucionais de qualidade e produtividade.

Descritores: Enfermagem de centro cirúrgico. Indicadores de gestão. Procedimentos cirúrgicos operatórios.

Título: Tempo de limpeza e preparo de sala: relação com o porte cirúrgico e perspectivas profissionais.

\section{RESUMEN}

El objetivo de comprobar la asociación entre el tiempo de limpieza y preparación de la sala quirúrgica (TLPS) con el porte quirúrgico y relacionar con las ventajas y dificultades asignadas a esta tarea por los circulantes de la sala. Método mezclado con enfoque cuantitativo transversal, retrospectivo, con muestra de 3095 cirugías realizadas de enero a junio de 2011 y; enfoque cualitativo de Análisis de Contenido Temático sobre el discurso de 11 circulantes. El promedio del TLPS fue menor en las cirugías de porte 1 aumentando en portes de 2, 3 y 4, con diferencia significativa. Las facilidades divulgadas fueron sobre organización y dimensionamiento de personal, y las dificultades en materiales afilados mezclados con instrumentos quirúrgicos y número reducido de profesionales de la limpieza. Cuanto mayor sea el porte más grande el TLPS. Los equipos quirúrgicos que operan en el Centro de Cirugía interfieren directamente en el proceso, facilitando o dificultando el logro de objetivos institucionales de calidad y productividad.

Descriptores: Enfermería de quirófano. Indicadores de gestión. Procedimientos quirúrgicos operativos.

Título: Tiempo de limpieza y preparación de quirófano: relación con el porte quirúrgico, facilidades y dificultades.

a PhD in Public Health, Nurse at the Nursing Department of the Botucatu Medical School (BMS) -UNESP - Univ Estadual Paulista, Botucatu, São Paulo, Brazil.

b Working on a PhD in Nursing, Nurse at the Nursing Department of BMS - UNESP _ - Univ Estadual Paulista, Botucatu, São Paulo, Brazil

c Working on a PhD in Nursing, Professor of the graduate course in Nursing for the Jaú Integrated Colleges and the Southeast Paulista College - Avaré, São Paulo, Brazil.

d PhD Professor of the Nursing discipline at the Surgical Center of the Nursing Department of BMS - UNESP - - Univ Estadual Paulista, Botucatu, São Paulo, Brazil.

e Professor at the Department of Biostatistics at the Institute of Biosciences -UNESP - - Univ Estadual Paulista, Botucatu, São Paulo, Brazil.

f PhD Professor of the Pneumology discipline. Department of Clinical Medicine of the BMS - UNESP - - Univ Estadual Paulista, Botucatu, São Paulo, Brasil. 


\section{INTRODUCTION}

To evaluate the performance of the healthcare units and assessment of the healthcare management services, focusing of the quality of care, using indicators that demonstrate the evolution, over time, allowing for comparison with internal and external references. A minimum set of data must be used, indispensible for the description and monitoring of its practice, recognizing these tools for evaluation and improvement of healthcare ${ }^{(1)}$. And, it is in this context that the time variable is extremely relevant for studying a surgical environment as a quantitative indicator, since it is closely linked to the quality and productivity of a service ${ }^{(2)}$. Cleaning time and operating room preparation (TLPS) control has been a concern reported in the literature ${ }^{(2-5)}$.

TLPS starts when the circulator returns to the operating room after the patient is sent to the anesthesia recovery room, until it is cleared for the next patient. It does not include the time between cases, also called the time between surgeries (IC) $)^{(5)}$. This activity involves the circulator of the room, the surgical scrub nurse and the hospital hygiene team $^{(5)}$. TLPS is the result of the actions of various teams that are linked through the assistance that they provide the patients, despite the differences and various interests.

Studies show that the average time spent on cleaning and preparing the operating room varied between $20^{(2)}$ a $28.8^{(3)}$ minutes, on average, and there is no consensus in the literature about the ideal time, considering the multiple diversities between the services.

The delay in starting a surgical procedure interferes directly with the subsequent surgeries, causing wear on the professionals that try to optimize the time to include all the activities pro$\operatorname{posed}^{(2-3)}$. The reasons for the delay may be related to the actual work process of the support sectors, inpatient units or surgical team, but also to the processes performed at the Surgical Center (SC) such as the TLPS ${ }^{(2-4)}$.

Evaluation of the TLPS leads to a critical review of the principal processes and routines involved in the surgical production of the hospital, allowing for intervention in the failed methods and development of improvements, seeking process quality ${ }^{(4)}$. The nurse, for improvement of this indicator, must, as an attribution, know how to lead the nursing team to obtain the best results while maintaining quality care $^{(4)}$.

Considering the above, we ask: Is there a connection between the TLPS and the size of the surgery? What are the advantages and difficulties attributed to this task by the room circulators?

To answer these questions, the study's objective is to verify the association between TLPS and surgery size and relate it to the advantages and difficulties attributed to this task by the operating room circulators (technicians and nursing assistants) at the $\mathrm{SC}$ of a Teaching Hospital in the interior of São Paulo.

\section{METHOD}

A mixed method was adopted, using a quantiqualitative approach. In the quantitative approach, a transversal and retrospective study was done, seeking to verify the association between TLPS and surgery size. In the qualitative approach, the objective was to learn about advantages and difficulties attributed to the room circulators when cleaning and preparing the operating room in order to connect them to the proposed association, to elucidate the different facets of the phenomenon.

The study was performed at the SC unit of a teaching hospital, located in the interior of São Paulo, made up of 12 operating rooms that host surgeries of all sizes and various specialties. An average of about 700 surgeries are performed per month. Elective surgeries are done on business days from 7 am to 4:30 pm, which is the latest possible time to start the last surgery. The nighttime, weekends and holidays are intended for urgent and emergency surgeries.

The TLPS recommended for the institution and put in place as a goal for the room circulators should be less than or equal to 30 minutes, no specifying the time for each activity to be done. The execution of this activity involves three steps: removal of instruments and surgical drapes and disinfection of equipment by the circulators; concurrent cleaning of the room by the hospital hygiene team (ceiling, walls, floor and surfaces); and preparation of the room for the next surgery, done by the room circulator.

There are approximately 40 circulators per room at the unit that alternate proportionally per period with one circulator per room and one hall 
circulator per period. The hospital hygiene service is provided by a third party company and, regarding the number of employees, they also alternate, maintaining a ratio of three employees per period within the SC unit. The hygiene service request for room cleaning is done by the nurse or room circulator of the SC. The surgery times and the TLPS are noted on a print out by the room circulators and subsequently typed into a computerized system for the institution's surgeries.

A sample of the quantitative approach was made up of all the surgeries that took place on business days from 7 am to $7 \mathrm{pm}$ in the months from January to June 2011, as well as the TLPS, whose information is available in the file of the computerized system for surgeries done at the institution. The data collected included: number of surgeries, surgery time, surgery size and TLPS, whereas:

- Surgery time: the time that the surgery lasted, in minutes;

- Surgery size: time that the surgery lasts, categorized by Size 1 (time of o to 120 minutes), Size 2 (time of 121 to 240 minutes), Size 3 (time of 241 to 360 minutes) and Size 4 (over 360 minutes) ${ }^{(5)}$.

- TLPS: time, in minutes, between when the circulator returns to the operating room from the anesthesia recovery room, until when the operating room is free for the next patient, according to the circulator's printed registry in the actual room.

The surgeries that were not adequately reported in the system's file (326 surgeries) were excluded, as were those that took place at night, on weekends and on holidays (722 surgeries). Therefore, the sample was made up of 3095 surgeries and TLPS.

To verify the degree and direction of the association between the surgery time and the TLPS, the Pearson Linear Correlation Analysis technique was used and, to verify the association between the TLPS and the surgery size, the data was evaluated using the analysis of variance technique (ANOVA) for the model, with a factor (size of surgery on four levels) complemented by the Tukey multiple comparison test between all the pairs of averages, considering a $5 \%$ significance level $^{(6)}$. The program used was SigmaStat for Windows version 3.5.

For the quantitative approach, data collection was done in the months from September to November 2011, using a non-probability sample, consisting of the room circulators that agreed to participate in the study and excluded the ones that were on vacation, medical leave or pregnant at the time when the sample was collected.

A pilot test was done with two nurses from the SC unit, which voluntarily excused themselves from collaborating in the study, for the purpose of adapting the questions guiding the questionnaire.

After the pilot was performed, not including the analysis, the first part of the questionnaire was made up of questions for characterizing the subject with information about sex, age, education and time working as a room circulator, and another part made up of two main questions: 1) What are the advantages you have found for cleaning and preparing the operating room? 2) What are the difficulties you have found for cleaning and preparing the operating room? The questionnaires were delivered to the subjects to be self-administered and answered manually, at an opportune time and location, at their choosing and, after completion, returned to the researchers.

For organization and analysis of the qualitative data from these questions adopted as a methodological approach to the Thematic Content Analysis according to $\operatorname{Bardin}^{(7)}$. This technique is made up of three phases: pre-analysis (organization of data, initial reading of all the content, choice of documents or records and determination of criteria); exploration of the material (codification themes, which allow us to reach the thematic representation of the content, composing the categories) and; interpretation (the data is treated in a way that it is significant and valid $)^{(7)}$. The findings were discussed, relating them to scholars of the theme.

To grantee the proposed confidentiality, the subjects' responses were organized according to an alphanumeric code: Circulator $1(\mathrm{C} 1)$, Circulator 2 (C2), and so on.

All of the data was collected after authorization from the institution and approval of the project by the Research Ethics Committee of the Botucato School of Medicine (Comitê de Ética em Pesquisa da Faculdade de Medicina de Botucatu) (Protocol CEP $4020-2011)$ and after the subjects of the study had signed the Statement of Informed Consent.

\section{RESULTS}

The sample was made up of 3095 surgeries, $1880(60.7 \%)$ of which were size $1,907(29.3 \%)$ of 
which were size $2,228(7.4 \%)$ of which were size 3 and $80(2.6 \%)$ of which were size 4 surgeries. The average times for surgery and TLPS, according to the size of the surgery, are presented in Figure 1. It was found that the average TLPS was lower for size 1 surgeries, increasing progressively with size 2, 3 and 4 surgeries. The percentage of TLPS that was greater than the goal stipulated by the institution, i.e., greater than or equal to 30 minutes, also increased according to the surgery size, reaching values of $11.12 \%, 19.18 \%, 30.26 \%$ and $36.25 \%$ for sizes 1, 2, 3 and 4, respectively.

Comparing the surgery times with the average for the TLPS, the Pearson correlation coefficient was calculated, considering the midpoints of the classes of values formed from the time of surgery. Therefore, 107 classes of pairs of values were established, whose point dispersion is represented in Figure 2 and it was found that the correlation coefficient is significant, representing a positive and moderate association between the variables, i.e., the longer the time for surgery, the longer time it took to clean and prepare the room.

When comparing the surgery size with the average TLPS, it was found that there is a significant difference between all the surgery sizes $(p<0.001)$, i.e., the larger the surgery size, the longer the TLPS.
11 room circulators participated in the study, four of which were nursing assistants and seven of which were nurse technicians; nine were female and two were male. The average age was 38 years old, varying from 25 to 61 years old. The average time that each had worked as a room circulator was 9 years, varying between 1 and 23 years.

From the analysis of what the subjects said, the following thematic categories emerged: Facilitating Factors - organization of the professionals during the surgical procedure and adequate number of nursing professionals; Hindering Factors - a large number of instruments/pieces of equipment used in the surgery, behavior of the teams, reduced number of cleaning professionals and sharps mixed with the surgical equipment.

\section{DISCUSSION}

This study showed that when the size of the surgery is larger, the TLPS is longer, corroborating the findings of the study performed at a SC specializing in oncology, whose average TLPS, after performing a size 1 surgery, was $32.10 \mathrm{~min}$, increasing to $33.64 \mathrm{~min}, 35.33 \mathrm{~min}$ and $36.23 \mathrm{~min}$, respectively for sizes 2,3 and $4^{(8)}$. However, using just the time indicator is not sufficient for making strategic decisions. There is the need to investigate

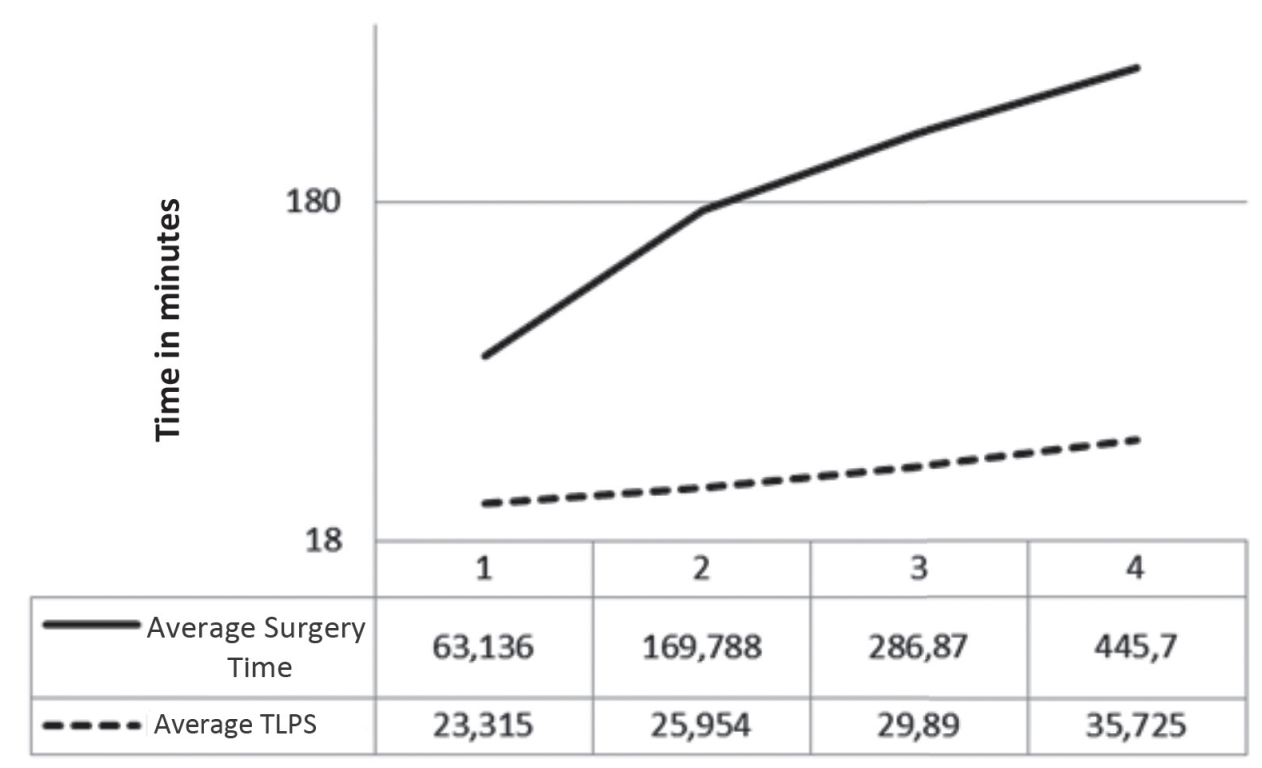

Figure 1 - Graph representation of the Average surgery Times (in minutes) and TLPS (in minutes_ according to Surgery Size, Hospital das Clínicas de Botucatu, 2011. 


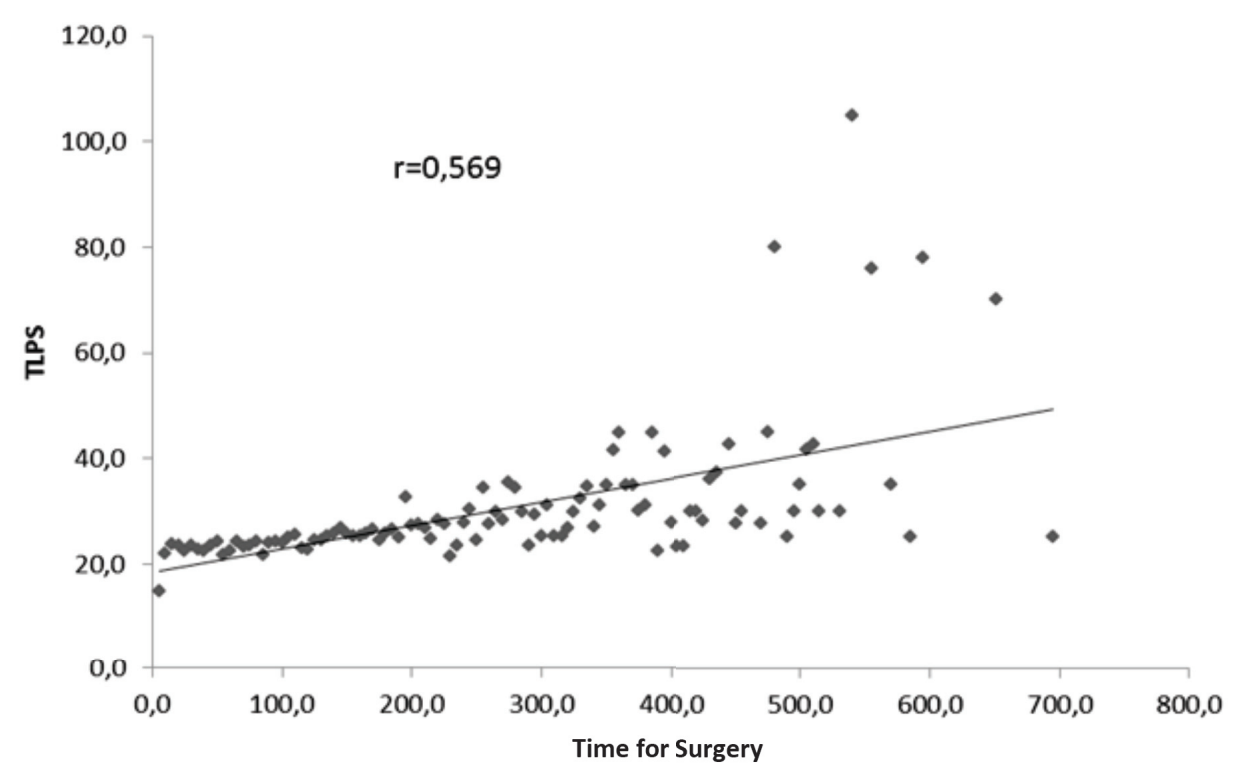

Figure 2 - A scatter diagram between the variable surgery times (in minutes) and TLPS (in minutes), Hospital das Clínicas de Botucatu, 2011.

Source: Research Data.

the work processes so that the interventions have an appropriate result. For the SC staff, as a result of its structure, the interaction between the members is essential, since the objectives will only be achieved from a joint effort. Thus, after listening to the subjects, thematic categories emerged, which supplemented the findings of the quantitative data.

\section{Facilitating Factors}

\section{Organization of the professionals during the surgical procedure}

As for the organization of the teams involved (nursing, anesthesiologists and surgeons) both a positive and negative influence was found, in accordance with the organization or disorganization, respectively, not only in relation to the dynamic of the operating room, but also in relation to the individual behavior of each professional toward the routing of the task of cleaning and preparing the room.

[...] Some residents (physicians) helped with our service and put the drapes properly into the hamper [...] (C2)

[...] When the circulator keeps the room organized throughout the surgery $[\ldots](C 7)$
[...]When the scrub nurse separates the sharps, it helps a lot $[\ldots](\mathrm{C} 8)$

\section{[...]Organized table of instruments $[\ldots](\mathrm{C} 4)$}

The nature of a work teams invariably involves dependence between the members of the staff, to a greater or lesser degree. The interdependence of tasks is the extension to which the members of the group must interact and depend on one another to complete the work satisfactorily ${ }^{(9)}$. The effectiveness of the work teams can be considered the final result of the performance of the interaction between the teams ${ }^{(10)}$, which was not observed when listening to the subjects, who considered the singularity of the activity. However, the concept of self-efficacy, defined as the general beliefs of individuals regarding their ability to achieve success ${ }^{(9)}$, was observed. This was reported by subject $\mathrm{C} 5$, for believing that he or she can, while performing the tasks, keep the TLPS within the institutional goals.

[...]I always clean the room within 15 to 20 minutes, which I think is enough time, even with a room that has a lot of instruments and tables. I do not believe I have ever taken more than twenty minutes (C5) 


\section{Adequate number of nursing professionals}

The number of human resources necessary to perform an activity is also important. We observed that a better amount of nursing staff is regarded as a facilitating factor, so that an increase in the number of people facilitates the execution of the task and allows for the TLPS to decrease.

[...] When we have two circulators in the operating room, one helps lead the patient out and the other works on picking up the materials [...] (C5)

[...] When there is a circulator available to help clean the room, it helps a lot to facilitate and speed up cleaning $[\ldots](C 6)$

Interventions to reduce prolonged TLPS may involve adjustments to the staff's working hours and a restructuring of the work processes. A study that sought to identify the nursing activities performed in the perioperative period, classify and validate the intervention activities, according to the Nursing Intervention Classification (NIC), showed that the recognition of the nursing interventions allows us to measure the time spent on their execution, a variable that is fundamental for quantifying and qualifying the work load of the professionals ${ }^{(11)}$.

An American study considered that practices for improving efficiency in the operating rooms, require institutional management processes so that the goals are reached, to monitor the improvements and give support and incentives to the teams' participants ${ }^{(12)}$.

\section{Hindering Factors}

\section{A large number of instruments/pieces of equipment used in the surgery}

The average TLPS for size 4 surgeries was higher than the time/goal established by the institution, which was to be less than or equal to 30 minutes, but the TLPS, was not just surpassed in size 4 surgeries, because the percentage of TLPS that surpassed the institutional goal, increasing in proportion to the size of the surgery, was possibly influenced by the complexity of the surgery. It is understood that longer surgeries may use more materials and surgical equipment, present a higher frequency of clinical and technical complications during the procedure and, therefore, justify longer room cleaning and preparation times. Another fact reported by the subjects in their statements, was that they found it difficult complete their duties in the time stipulated for surgeries that use a lot of instruments/equipment.

There are a lot of instruments to be picked up. (C7)

Cleaning the equipment $[\ldots]$ (C6)

Surgeries that use a lot of equipment and many instruments that need to be put away. (C3)

An investigation done in a private tertiary hospital showed fewer delays with long surgeries (surgeries that took longer than four hours, standardization established in the service). The goal of this hospital was to make the amount of time between the end of an anesthetic procedure and the start of the next one, not longer than 20 minutes. The goal was achieved in $88.3 \%$ of the surgeries studied ${ }^{(2)}$, which differs from the present study, performed in a public teaching hospital. Upon analyzing this data, we observed a paradox in the settings, private versus public, making it possible for us to consider that the dynamic of the work processes, or even the organizational culture of these hospitals, is related to reduced costs, in the private sector, and the particularities of academic teaching, in the public sector (university hospitals).

\section{Behavior of the nursing, surgical and anesthesiology teams}

A delay in the TLPS reflects negatively on the productivity of the SC and may interfere with the realization of other surgeries, as well as create conflicts between the teams. A national study showed that a third cause for cancelling surgery was the due to surpassing the time scheduled for elective surgeries. It is inferred that taking a long time to move the patients in the operating rooms may increase the rate of cancelled surgeries, as well as frustrate the teams that are waiting to provide services and the patients who must then postpone their treatment ${ }^{(13)}$.

But, the subjects' statements showed that it was the teams themselves that negatively influence the TLPS, in so much as they do not connect their behavior to the subsequent activities. 
Some surgeons remain in the room, talking, after the surgery has ended and they end up causing the cleaning to be delayed. (C1O)

When I am cleaning and a colleague comes to talk [...] (C9)

When the surgeons and anesthesiologists do not put the materials in the right place. (C11)

\section{Reduced number of cleaning professionals}

Through the reports, we observed that a significant impasse is caused by a reduced number of professionals from the hospital hygiene sector, causing a delay in the activity to be performed, with a consequent increase in the TLPS.

The cleaning team is busy. (C1)

When the cleaner is cleaning another room. (C6)

When the cleaning team is cleaning another room. (C2)

When it is time for the cleaning staff to change shifts, the room cleaning gets delayed. (C1O)

There are few cleaning professionals. (C7)

This study did not analyze, separately, the time spent by each team, which limited the analysis of this thematic category. However, we realize the importance of separating these times for specific adaptations of each team.

A study performed in a teaching hospital, with a sample of 101 surgeries, where the variable time was investigated to measure the concurrent cleaning activities of the room and the time between surgeries, observed that the time it took for the hospital hygiene service to clean the operating room was not influenced by the size and specialty of the surgery, nor the time of day when the surgery took place. The size of the room also did not affect the cleaning time, but the circulator's activities were not timed. Therefore, it was not possible to determine how much of this time was used in the process of preparing the rooms and, consequently, compare it with the size of the surgery ${ }^{(3)}$.

Thus, it can be inferred that there is a need for effective communication between the nursing and cleaning teams, so that everyone can reach their goals with commitment and efficacy, since the synchronization of tasks is essential for reducing the TLPS.

\section{Sharps mixed with the surgical instruments}

Another situation indicated by various subjects is the incorrect separation and disposal of sharps by the surgeons and scrub nurses, which, in addition to fostering possible occupational accidents, also increased the TLPS.

Sharps mixed with surgical instruments requires a lot of attention from the circulator and ends up taking more time. (C11)

When the surgeons do not separate the sharps. (C6)

Surgeries where the sharps are not separated.(C3)

Having to separate sharps and materials thrown on the floor. (C4)

Sharps among the instruments. (C7)

This problem assumes not only an individual non-compliance, but also an organizational and institutional problem, which is the health of the healthcare professional. This brings us to a work environment exposed to dangerous and hazardous situations that could be perfectly preventable.

A study performed in Rio de Janeiro that looked at 15,035 cases of exposure to biological material, found that almost $90 \%$ of exposures were related to subcutaneous injuries with sharps and $35 \%$ of them were reported by nursing assistants, $14 \%$ of which were due to handling surgical equipment.

The improper disposal or packaging of waste, being a source of accidents, indicates the need to broaden prevention interventions among all those who act in the Surgical Centers ${ }^{(14)}$. An investigation, whose objective was to understand the significance of work-related accidents with exposure to biological material from the perspective of nursing professionals, showed that they did not recognize the work environment as a potential predictor of occupational accidents, but recognize the risks to which they are exposed. However, they do not change their behavior because of the selfconfidence acquired through years of professional 
experience $^{(15)}$. The literature points to the need for continuous education, approaching topics regarding the planning and execution of technical procedures, as well as recognizing and not trivializing the occupational risks ${ }^{(14-16)}$, which are extremely relevant to the surgical environment.

For managing this setting, the literature points to the nurse manager's job of evaluating the work processes, and his or her ability to use information generated by the indicators to make a decision, therefore becoming fundamentally important to the continuous search for standards of excellence ${ }^{(2-4)}$. It also indicates that all professionals must feel as though they are participants and responsible for the production and use of the information generated by the indicators, so that there is an institutional culture that values the information ${ }^{(17)}$.

\section{CONCLUSION}

We have concluded that the TLPS is related to the surgery size and that the teams working in the $\mathrm{SC}$ interfere directly in the process, facilitating or hindering the achievement of the institutional goals, demonstrating the importance of interdependence between the teams in order to increase the quality and productivity of the SC.

We recommend that the steps for cleaning the operating room are widely discussed and standardized by the teams working in the $\mathrm{SC}$, with the possibility for establishing the TLPS according to the size of the surgery.

One of the limitations of this study was using the TLPS from the institutional database and not from direct observation, as well as not having computed, separately, the time that the circulator took for cleaning and the time that the hospital hygiene team took to clean, which would have allowed actions specific to each group. However, this study offers contributions for managing the SC unit and for the national literature, since the topic has been only lightly addressed. Thus, we recommend that new research is done in other settings, including, in addition to the TLPS, the time between surgeries and the quality of the service provided, i.e., an evaluation, using measurable methods, of the effectiveness of the cleaning process, such as using microbiological parameters and an evaluation of organic material using adenosine triphosphate (ATP) bioluminescence.

\section{REFERENCES}

1 Gabriel CS, Melo MRAC, Rocha FLR, Bernardes A, Miguelaci T, Silva MLP. Utilização de indicadores de desempenho em serviço de enfermagem de hospital público. Rev Latino-Am. Enfermagem [Internet]. 2011 set-out [citado 2013 set 09];19(5):[09 telas]. Disponível em: http://www.scielo.br/pdf/rlae/v19n5/pt_24.pdf

2 Nepote MHA, Monteiro IU, Hardy E. Associação entre os índices operacionais e a taxa de ocupação de um centro cirúrgico geral. Rev Latino-Am Enfermagem. 2009; $17(4): 529-34$.

3 Jericó MC, Perroca MG, Penha VC. Mensuração de indicadores de qualidade em centro cirúrgico: tempo de limpeza e intervalo entre cirurgias. Rev Latino-Am Enfermagem. 2011;19(5):1239-46.

4 Sousa CS, Akamine J. Aplicação de indicadores para análise de desempenho do centro cirúrgico. Rev Adm Saúde. 2008;10(41):141-50.

5 Possari JF. Centro cirúrgico: planejamento, organização e gestão. 4. ed. São Paulo: Iátria; 2009. 288p.

6 Zar JH. Biostatistical analysis. 58th ed. New Jersey: Prentice Hall; 2010. 960p.

7 Bardin L. Análise de conteúdo. São Paulo: Edições 70; 2011.279p.

8 Possari JF. Dimensionamento de profissionais de enfermagem em centro cirúrgico especializado em oncologia: análise dos indicadores intervenientes [dissertação]. São Paulo (SP): Escola de Enfermagem, Universidade de São Paulo; 2011.

9 Meneses PPM, Abbad GS. Construção e validação de um instrumento para avaliar auto-eficácia em situações de treinamento, desenvolvimento e educação de pessoas. Psicol Reflex Crít. 2010;23(1):141-50.

10 Puente-Palacios K, Borba ACP. Equipes de trabalho: fundamentos teóricos e metodológicos da mensuração de seus atributos. Aval Psicol [Internet]. 2009 dez [citado 2013 set 09];8(3):369-79. Disponível em: http://pepsic.bvsalud.org/scielo.php? script $=$ sci_ arttext\&pid=S1677-047 12009000300009\&lng=pt.

11 Possari JF, Gaidzinski RR, Fugulin FMT, Lima AFC, Kurcgant P. Padronização das atividades em centro cirúrgico oncológico segundo a classificação das intervenções de enfermagem. Rev Esc Enferm USP. 2013; 47(3):600-6. 
12 Krupka DC, Sandbergb WS. Operating room design and its impact on operating room economics. Curr Opin Anaesthesiol. 2006;19(2):185-91.

13 Avila MAG, Bocchi SCM. Telephone confirmation of a patient's intent to be present for elective surgery as a strategy to reduce absenteeism. Rev Esc Enferm USP. 2013;47(1):193-7.

14 Rapparini C, Saraceni V, Lauria LM, Barroso PF, Vellozo V, Cruz M, et al. Occupational exposures to bloodborne pathogens among healthcare workers in Rio de Janeiro, Brazil J Hosp Infect. 2007;65(2):131-7.
15 Magagnini MAM, Rocha SA, Ayres JA. O significado do acidente de trabalho com material biológico para os profissionais de enfermagem. Rev Gaúcha Enferm. 2011 jun;32(2):302-8.

16 Silva TR, Rocha SA, Jairo Ayres JA, Juliani CMCM. Acidente com material perfurocortante entre profissionais de enfermagem de um hospital universitário. Rev Gaúcha Enferm. 2010 dez;31(4):615-22.

17 Simões e Silva C, Gabriel CS, Bernardes A, Évora YDM. Opinião do enfermeiro sobre indicadores que avaliam a qualidade na assistência de enfermagem. Rev Gaúcha Enferm. 2009 jun;30(2):263-71.

\author{
Author's address / Endereço do autor / \\ Dirección del autor \\ Marla Andréia Garcia de Avila \\ Rua Damião Pinheiro Machado, 751, ap. 13, Centro \\ 18603-560, Botucatu, SP \\ E-mail:marla@fmb.unesp.br
}

Received: 10.09.2013

Approved: 24.02.2014 